\title{
Pengaruh Penambahan Gelling Agent Carbopol Dan Asam Stearat terhadap Nilai Kalor Etanol Gel
}

\author{
Erlinda Ningsih ${ }^{1}$, Kartika Udyani ${ }^{2}$, Dian Agus Saputra ${ }^{3}$, Silvi Natalia Fadilatut Talcha ${ }^{4}$ \\ 1,2,3,4 Jurusan Teknik Kimia, Institut Teknologi Adhi Tama Surabaya, Jl. Arif Rahman Hakim No. 100 \\ Surabaya, Indonesia
}

\begin{tabular}{|c|c|}
\hline INFORMASI ARTIKEL & ABSTRACT \\
\hline $\begin{array}{l}\text { Tanggal penyerahan: } \\
25 \text { Maret } 2021 \\
\text { Tanggal diterima: } \\
31 \text { Maret } 2021 \\
\text { Tanggal terbit: } \\
\text { 28 Juni } 2021\end{array}$ & $\begin{array}{l}\text { Ethanol gel is a semisolid fuel made from ethanol by mixing the gelling agent. } \\
\text { Ethanol gel has the advantage of facilitating packaging, distribution and storage } \\
\text { because it does not spill and flow easily. Another advantage of ethanol gel is that it } \\
\text { does not smoke during the combustion process, does not cause soot and does not } \\
\text { produce harmful gases. This research aims to compare the } 2 \text { best gelling agents } \\
\text { and study the effect of adding the gelling agent to the calorific value. The process } \\
\text { of making ethanol gel begins by inserting a gelling agent of } 4-12 \% \text { into a beaker } \\
\text { glass. Then add } 20 \mathrm{ml} \text { of distilled water while stirring until the solution thickens. } \\
\text { After that, slowly put } 75 \text { grams of } 95 \% \text { ethanol into the beaker which already } \\
\text { contains the gelling agent solution. For the manufacture of ethanol gel with a } \\
\text { stearic acid gelling agent, heating is done first in making the solution and left for } 3 \\
\text { hours after mixing with ethanol. Based on the analysis, it was found that the } \\
\text { highest calorific value was } 12052.7 \text { cal / } g \text { with stearic acid gelling agent in the } \\
\text { addition of } 12 \%(\% \text { w). }\end{array}$ \\
\hline
\end{tabular}

Keywords: ethanol gel, gelling agent, Carbopol, stearic acid, calorific value

EMAIL

${ }^{1}$ Erlindaningsih84@itats.ac.id

2Kudyani@itats.ac.id

\begin{abstract}
ABSTRAK
Gula rafinasi merupakan gula yang diproduksi dari bahan baku gula mentah / raw sugar melalui proses rafinasi untuk menghilangkan kotoran serta mollases yang menempel pada Raw sugar. Proses yang akan digunakan dalam pembuatan gula rafinasi dari raw sugar dengan pemurnian karbonatasi dibagi menjadi tujuh tahapan yaitu: proses afinasi, proses klarifikasi, proses filtrasi, proses dekolorisasi, proses evaporasi, proses kristalisasi, proses pengeringan. Pabrik direncanakan beroperasi 300 hari per tahun dengan kapasitas 100.000 ton per tahun. Pabrik direncanakan akan didirikan di daerah Kabupaten Sambas, Kalimantan Barat. Dari hasil analisa ekonomi didapatkan: Internal Rate Of Return (IRR) sebesar 66\%, Pay Out Time (POT) sebesar 3,3 tahun, Break Even Point (BEP) sebesar 36\%. Berdasarkan analisa teknis dan ekonomi yang telah dilakukan, maka pabrik gula rafinasi dari raw sugar ini layak didirikan.
\end{abstract}

Kata kunci: etanol gel, gelling agent, Carbopol, asam stearate, nilai kalor

\section{PENDAHULUAN}

Gula rafinasi atau refined sugar merupakan gula mentah yang sudah mengalami proses pemurnian sehingga berkualitas tinggi karena kadar abu dan kadar belerang (SO2) yang mendekati nol (Agrirafinasi,2013). Gula rafinasi banyak digunakan dalam industri pangan dan farmasi. Dari tahun ke tahun pertumbuhan industri pangan maupun farmasi di Indonesia semakin mengalami peningkatan. Peranan gula rafinasi bagi industri ini adalah sebagai salah satu bahan baku produksi. Secara tidak langsung dapat dikatakan bahwa kelancaran produksi industri pangan dan farmasi sangat bergantung pada ketersediaan gula rafinasi. Dengan bertambahnya jumlah industri pangan 
dan farmasi di Indonesia, berdampak pada meningkatnya kebutuhan gula rafinasi nasional. Pada awalnya gula rafinasi belum dapat diproduksi di dalam negeri sehingga kebutuhan industri dipenuhi melalui melalui impor. Sampai tahun 1996 seluruh kebutuhan industri dalam negeri masih dipenuhi melalui impor gula rafinasi (Agrirafinasi,2013). Sampai saat ini pemenuhan kebutuhan akan gula rafinasi nasional tidak hanya dipenuhi dari pasokan gula rafinasi dalam negeri tetapi juga masih mengimpor dari negara penghasil.

Pengamat pertanian Khudori menjelaskan, dari sejarahnya, gula kristal rafinasi (GKR) diadakan untuk memenuhi kebutuhan pemanis industri yang tidak bisa dipenuhi pabrik gula (PG) yang ada. Ada dua cara yang bisa dilakukan untuk memenuhi kebutuhan GKR, yaitu impor sepenuhnya GKR atau mendirikan PG rafinasi dengan bahan baku gula mentah impor. Pemerintah menempuh cara kedua. (Neraca,2012).

Berdasarkan kajian yang dilakukan, maka perlu ada penilitian lebih lanjut dengan mengambil 2 jenis gelling agent terbaik untuk dibandingkan sehingga menghasilkan etanol gel berkualitas baik dengan melakukan analisa kualitatif dan kantitatif mengenai karakteristik etanol gel yang terbentuk meliputi warna nyala, lama nyala, dan nilai kalor.

\section{METODE}

Pada proses pembuatan gula rafinasi pada intinya adalah merubah gula mentah (raw sugar) menjadi gula rafinasi (refined sugar) yang dapat memenuhi syarat untuk digunakan sebagai bahan baku industri. Proses ini memiliki beberapa tahapan, yaitu 1. Proses Afinasi 2. Proses Klarifikasi 3. Proses Filtrasi 4. Proses Dekolorisasi 5. Proses Evaporasi 6. Proses Kristalisasi 7. Proses Pengeringan Pada perancangan pabrik kali ini dilakukan seleksi pada proses dekolorisasi karena proses ini sangat penting untuk hasil akhir gula rafinasi yang akan diperoleh.

\section{HASIL DAN PEMBAHASAN}

Pembuatan etanol gel dalam penelitian ini menggunakan bahan bakunya adalah etanol 95\%, bahan pengental Carbopol dan asam stearat. Hasil pembuatan etanol gel pada Gambar 2 terlihat bahwa secara visual etanol gel dengan pengental Carbopol lebih jernih dibandingkan dengan asam stearat. Visual etanol gel yang jernih disebabkan oleh proses pembuatan etanol gel, bahan pengental dicampur dengan aquades, sehingga rantai polimer yang terdapat pada pengental akan memanjang, senyawa polar, dan menyebabkan peningkatan kekentalan ${ }^{10}$. Karakteristik etanol gel disajikan pada Tabel 1 . 


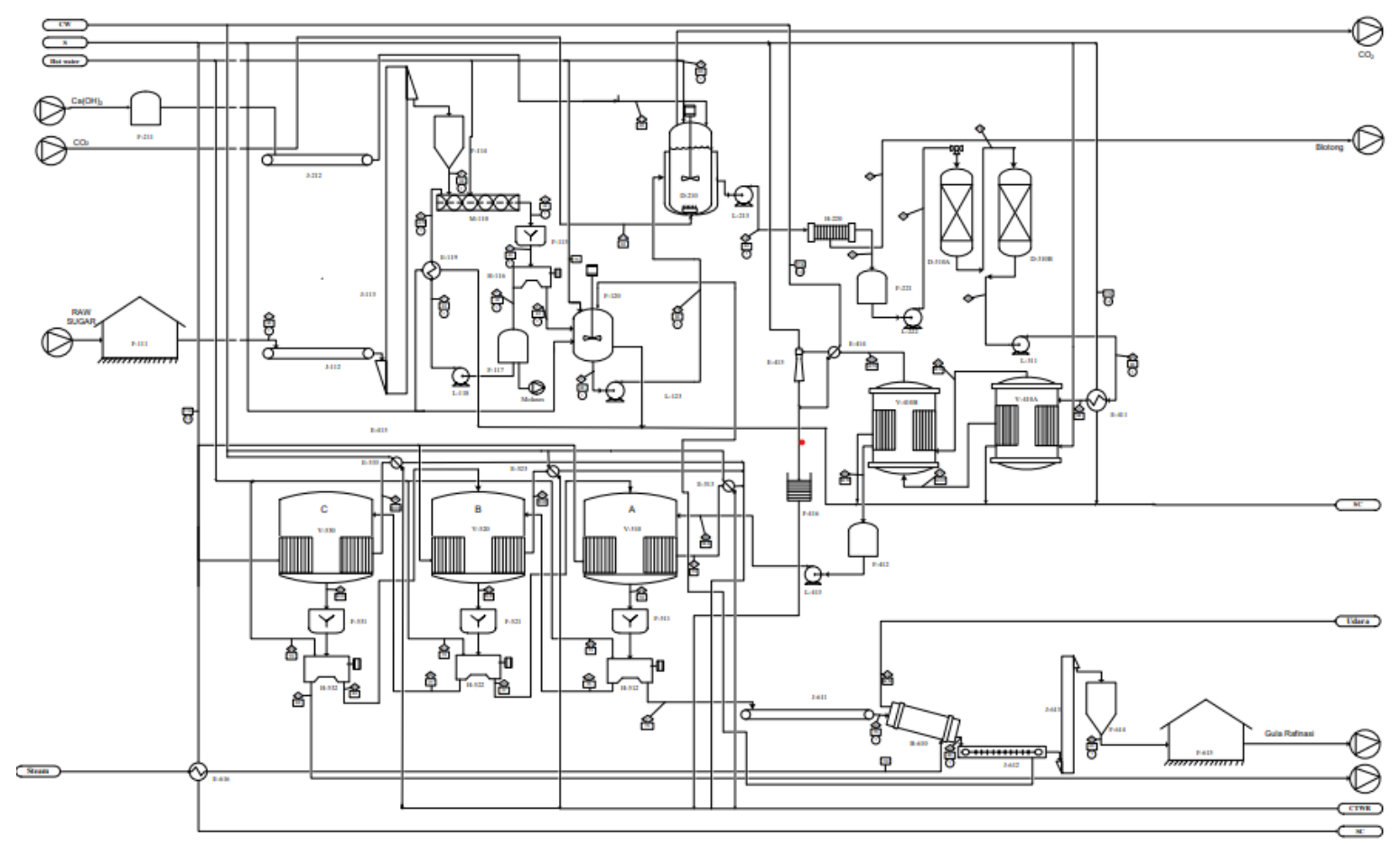

Gambar 1. a) Pembuatan etanol gel dengan gelling agent asam stearat; b) Pembuatan etanol gel dengan gelling agent Carbopol.

Sumber : dokumen pribadi redaksi

Gambar 2. Etanol Gel dengan Gelling Agent a). Carbopol; b). Asam stearat. Sumber : Dokumentasi pribadi

Dari hasil pengujian etanol gel dengan gelling agent carbopol dan asam stearat, warna nyala keduanya menunjukkan warna yang sama, yaitu mula-mula berwarna biru dan lama-lama menjadi kuning. Jika dibandingkan dengan parafin, warna etanol gel lebih bagus (berwarna biru) sehingga cenderung tidak menimbulkan jelaga. Sedangkan warna nyala paraffin berwarna kuning sehingga menimbulkan jelaga ${ }^{7}$. Hasil warna nyala terlihat pada Gambar 3.

Tabel 1. Data Biaya Fixed Cost, Variable Cost, Semi Variable Cost, dan Sell

\begin{tabular}{|c|c|c|c|}
\hline No. & KETERANGAN & \multicolumn{2}{|l|}{ JUMLAH } \\
\hline \multirow{5}{*}{$\begin{array}{l}1 . \\
2 .\end{array}$} & & \multicolumn{2}{|l|}{22.424 .494 .528} \\
\hline & Biaya variabel (VC) & \multirow{3}{*}{\multicolumn{2}{|c|}{$\begin{array}{l}916.410 .300 .000 \\
123.326 .276 .480\end{array}+$}} \\
\hline & - Bahan baku & & \\
\hline & - Utilitas & & \\
\hline & & 1.039 .736 .576 .480 & \\
\hline \multirow[t]{9}{*}{3.} & Biaya semi variabel (SVC) & & \\
\hline & - Tenaga kerja & 14.423 .500 .000 & \\
\hline & - $\quad$ Pemeliharaan dan perbaikan & 17.797.217.879 & \\
\hline & - $\quad$ Operating supplies & 1.779.721.788 & \\
\hline & - Laboratorium & 1.442 .350 .000 & \\
\hline & - $\quad$ Paten dan royalti & 12.332 .627 .648 & \\
\hline & - Plant overhead cost & 49.330 .510 .592 & \\
\hline & - $\quad$ Pengeluaran umum & 73.995.765.888 & + \\
\hline & & 171.101 .693 .795 & \\
\hline
\end{tabular}




\begin{tabular}{|l|l|c|} 
& & 171.101 .693 .795 \\
4. & Total penjualan $(\mathrm{S})$ & 1.365 .989 .130 .000 \\
\hline
\end{tabular}

Sumber : Dokumentasi pribadi

\section{Lama Waktu Nyala}

\section{Nilai Kalor}

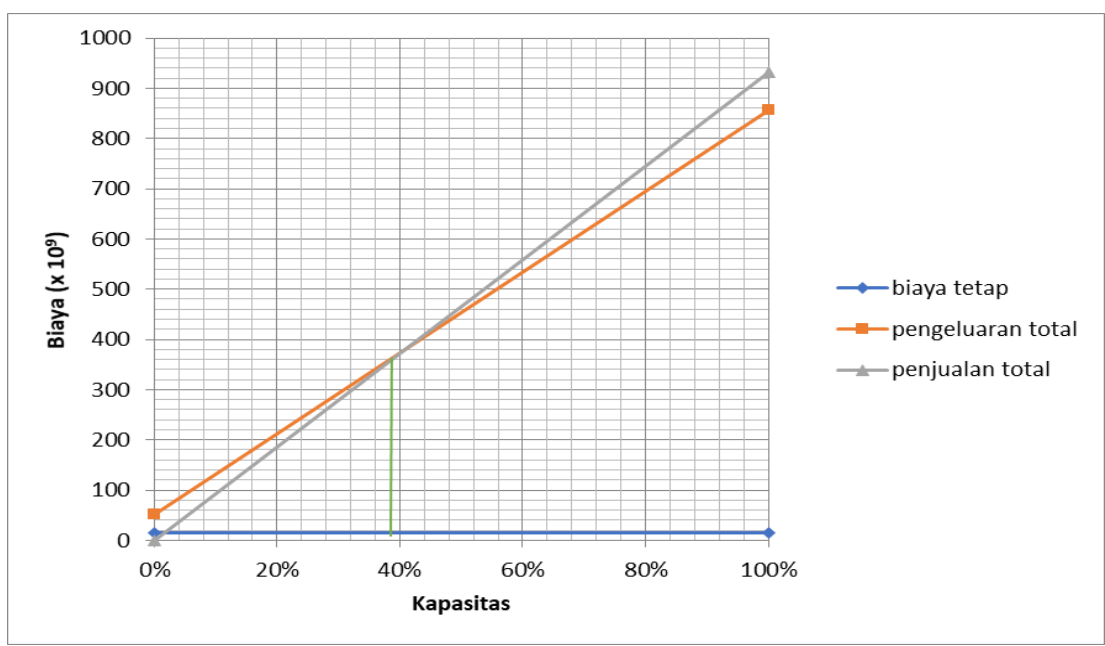

Gambar 4. Grafik Break Event Point Pabrik Gula Rafinasi

Gambar 5. Grafik Hubungan Penambahan Gelling Agent terhadap Nilai Kalor

\section{UCAPAN TERIMA KASIH}

Penulis mengucapkan terima kasih kepada YPTS dan Jurusan Teknik Kimia ITATS sehingga penelitian ini dapat berlangsung.

\section{KESIMPULAN}

Karakteristik etanol gel terbaik yang meliputi stabilitas nyala, lama waktu nyala dan $\%$ residu adalah menggunakan gelling agent carbopol dengan lama waktu nyala 202 detik dan \% residu $2,78 \%$ sedangkan dengan menggunakan gelling agent asam stearat memilikinilai kalor dan water boiling test terbaik dengan nilai 12052,7 kal/gr dan 6,15 menit.

\section{DAFTAR PUSTAKA}

[1] Amalia, Y. \& Muria, S. R. Pembuatan Bioetanol dari Limbah Padat Sagu Menggunakan Enzim Selulase dan Yeast Saccharomyces Cerevisiae dengan Proses Simultaneous Sacharificatian and Fermentation ( SSF ) dengan Variasi Konsentrasi Substrat dan Volume Inokulum. I, (2009).

[2] Dirgantara, D. A., Chairul \& Zultiniar. Pembuatan Bioetanol dari Ampas Sagu menggunakan Proses Hidrolisis dan Fermentasi Menggunakan Asam Sulfat sebagai Katalis. FTEKTNK 8, 1-9 (2021).

[3] Triaswati, I., Nurhayanti, L. \& Buchori, L. PEMBUATAN BIOETANOL GEL SEBAGAI BAHAN BAKAR ALTERNATIF PENGGANTI MINYAK TANAH.

[4] Hanun, V. \& Sutjahjo, D. H. Komparasi Karakteristik Bioetanol Gel dengan Pengental Karbopol dan carboxy Methyl Cellulose(CMC) sebagai Bahan Bakar 
Alternatif. 07, 14-20 (2018).

[5] Merdjan, R. \& Matione, J. fuel gel. (2003).

[6] Budi, S. \& Supriyatna, N. SELULOSA SEBAGAI PENGENTAL PADA PEMBUATAN. 59-64 (2013).

[7] Mulyono \& Suseno, T. PEMBUATAN ETHANOL GEL SEBAGAI BAHAN BAKAR PADAT ALTERNATIF. (2010).

[8] Matthews, J. Influence of clearing agent on immunohistochemical staining of paraffin-embedded tissue. 23-26 (1980).

[9] Monye, M. S. Extraction of cellulose from cacti. 9, 3869-3873 (2017).

[10] Nugroho, A., Restuhadi, F. \& Rossi, E. Pembuatan Gel Etanol dengan Menggunakan Bahan Pengental Carboxymethycellulose (CMC). 3, (2016).

[11] Wibowo, W. A., Suseno, T., Kimia, J. T., Teknik, F. \& Maret, U. S. Pembuatan dan uji pembakaran ethanol gel. 9, 67-71 (2010).

[12] Tyastando, R. D., Ardiansah, J., Pramudita, A. E. \& Riandadari, D. STUDI EXPERIMENTAL PEMBUATAN BIOETANOL GEL DENGAN PENGENTAL CARBOXYMETHYL CELLULOSE DAN PENGUJIAN PERFORMANCE BIOETANOL GEL. 1, (2019).

[13] Lloyd, P. J. D. \& Visagie, E. M. A comparison of gel fuels with alternative cooking fuels. 18, 26-31 (2007).

[14] A, D. A., S, H., S, D. K. \& S, M. R. Formulasi Bioetanol Padat dengan Variasi Gelling Agent sebagai Bahan Bakar Alternatif yang Ramah Lingkungan. Ind. Inov. 4, 13-19 (2014).

[15] Sutarsa, N. W. N. M. PENGARUH FORMULASI CARBOXYMETHYL CELLULOSE DAN ASAM STEARAT TERHADAP KARAKTERISTIK GEL BIOETANOL. 5, 18-27 (2017).

[16] Akhiroh, I. N. J. \& Sutjahjo, D. H. NISBAH KATALIS NATRIUM CARBOXYMETHYLCELLULOSE ( Na CMC ), ASAM STEARAT DAN BIOETANOL TERHADAP KARAKTERISTIK PEMBUATAN BIOETANOL PADAT DARI MOLASESS Islam Nur Jannatul Akhiroh Dwi Heru Sutjahjo Abstrak. 03, 160-166 (2015).

[17] Azis, I. J. PEMBUATAN ETHANOL GEL SEBAGAI BAHAN BAKAR SEMI PADAT ALTERNATIF DENGAN MENGGUNAKAN KARBOKSIMETIL SELULOSA (CMC) SEBAGAI GELLING AGENT. (2016). 